\title{
Failure of L-Carnitine to Protect Mice against Ammonia Toxicity
}

\author{
Devendra R. Deshmukh' and Cynthia D. Rusk \\ Department of Pediatrics and Biological Chemistry, University of Michigan, \\ Ann Arbor, Michigan 48109
}

Received July 23, 1987

High blood levels of ammonia are observed in several pathological conditions such as cirrhosis of the liver and inborn errors of the urea cycle. Elevated blood ammonia levels are toxic to the brain and central nervous system and lead to convulsions, coma, and death. Recent interest has centered on reducing elevated blood ammonia by increasing nitrogen excretion in the form of derived conjugates (1). A number of compounds that can protect animals against ammonia toxicity have been tested. These compounds include sodium benzoate, ethanol, phenylacetate, and carbamyl glutamate (2).

O'Connor et al. recently reported that an intraperitoneal injection of L-carnitine protected mice against ammonia toxicity $(3,4)$. They proposed that L-carnitine induced ureagenesis, resulting in decreased ammonia levels in blood and brain. The initial objective of our investigation was to confirm this observation in 2month-old ferrets which develop severe ammonia toxicity within $2 \mathrm{hr}$ after eating an arginine-free diet (5). Preliminary results showed that L-carnitine did not protect ferrets against the diet-induced ammonia toxicity. Therefore, we attempted to confirm the observation of the effects of L-carnitine on the mortality and ammonia levels in plasma, brain, and liver in mice. Our study shows that Lcarnitine failed to protect mice and ferrets from ammonia toxicity.

\section{MATERIALS AND METHODS}

A powder form of L-carnitine hydrochloride was purchased from Sigma Chemical Co. (St. Louis, MO) and an injectable form of L-carnitine was purchased from Sigma-tau Co. (Rome, Italy). Other chemicals used were of analytical grade.

Animals. Male Swiss Albino mice, weighing 25-30 g, were purchased from Charles River Laboratories (Wilmington, ME) and were maintained on Purina rodent chow. Two month-old, male, sable-coated ferrets were purchased from Marshall Farm (North Rose, NY) and were maintained on Purina cat chow. An arginine-free diet was prepared as described previously $(5,6)$.

Experimental design. Twelve ferrets were divided into two groups of six animals

'To whom reprint requests should be addressed. 
TABLE 1

Effect of L-Carnitine on Mortality in Mice Challenged with Ammonium Acetate“

\begin{tabular}{lccc}
\hline & \multicolumn{2}{c}{ Number of animals } & Percentage \\
\cline { 2 - 3 } Treatment & Injected & Died & 0 \\
Saline & 8 & 0 & 0 \\
L-carnitine & 6 & 0 & 71 \\
Saline + ammonium acetate & 14 & 10 & 79 \\
Carnitine + ammonium acetate & 19 & 15 & . \\
\hline
\end{tabular}

${ }^{a}$ Mice were injected ip with either saline or with L-carnitine $(16 \mathrm{mmole} / \mathrm{kg})$. Thirty minutes later, ammonium acetate was injected (ip, $14 \mathrm{mmole} / \mathrm{kg}$ ) and mice were observed for mortality.

each. All ferrets were fasted for $16 \mathrm{hr}$ and then fed an arginine-free diet at 9:00 AM. At 10:30 AM ferrets in group 1 were injected (ip) with saline and ferrets in group 2 were injected intraperitoneally (ip) with $8 \mathrm{mmoles} / \mathrm{kg}$ of L-carnitine. At 12:30 PM blood was collected in chilled heparinized tubes and centrifuged at $6000 \mathrm{~g}$ for $15 \mathrm{~min}$ and plasma was separated. Ammonia in plasma was determined as described below.

Preliminary experiments were conducted in mice to determine the lethal dose of ammonium acetate. Mice were injected (ip) with an increasing dose of ammonium acetate ranging from $1-18 \mathrm{mmole} / \mathrm{kg}$ and the effect on mortality was studied.

In other experiments (Tables 1 and 2) mice were divided into four groups as follows: 1, saline; 2, L-carnitine; 3 , saline plus ammonium acetate; and 4, Lcarnitine plus ammonium acetate. Mice from groups 1 and 3 were injected (ip) with $0.5 \mathrm{ml}$ of saline and mice in groups 2 and 4 were injected (ip) with 16

TABLE 2

Effects of L-Carnitine and Ammonium Acetate on Ammonia and Urea Levels in Serum, Liver, and Brain of Mice ${ }^{a}$

\begin{tabular}{lrrrr} 
Parameter & Saline & L-Carnitine & $\begin{array}{c}\text { Saline plus } \\
\text { ammonium acetate }\end{array}$ & $\begin{array}{c}\text { L-Carnitine plus } \\
\text { ammonium } \\
\text { acetate }\end{array}$ \\
\hline Ammonia $^{b}$ & & & & \\
$\quad$ Serum $(\mu \mathrm{mole} / \mathrm{liter})$ & $234 \pm 24$ & $474 \pm 45^{c}$ & $3561 \pm 392^{c}$ & $4784 \pm 564^{c}$ \\
Liver $(\mu \mathrm{mole} / \mathrm{g})$ & $2.4 \pm 0.5$ & $1.3 \pm 0.1^{c}$ & $7.7 \pm 0.7^{c}$ & $9.9 \pm 0.8^{c . d}$ \\
Brain $(\mu \mathrm{mole} / \mathrm{g})$ & $3.3 \pm 0.2$ & $2.1 \pm 0.1^{c}$ & $3.7 \pm 0.5$ & $4.5 \pm 0.4^{c}$ \\
Urea & & & & \\
$\quad$ Serum (mmole/liter) & $11.3 \pm 0.6$ & $12.6 \pm 0.7$ & $15.0 \pm 0.9$ & $15.8 \pm 0.6$ \\
$\quad$ Liver $(\mu$ mole/g) & $4.9 \pm 0.5$ & $8.2 \pm 0.3^{c}$ & $11.2 \pm 0.8^{c}$ & $12.0 \pm 0.3^{c}$ \\
$\quad$ Brain $(\mu$ mole/g) & $4.9 \pm 0.3$ & $7.8 \pm 0.4^{c}$ & $7.0 \pm 0.3^{c}$ & $8.5 \pm 0.4^{c}$ \\
\hline
\end{tabular}

${ }^{a}$ Injections were administered as described in Table 1. Five minutes after the ammonium acetate injection, blood, liver, and brains were removed.

${ }^{b}$ Results are means \pm SEM. $n>9$. Statistically significant differences $(P<0.05)$ are indicated by ${ }^{c}$ when compared with the saline group and ${ }^{d}$ when compared with the saline plus ammonium acetate group. 
mmole $/ \mathrm{kg}$ of L-carnitine. Thirty minutes later ammonium acetate $(14 \mathrm{mmole} / \mathrm{kg}$, as $0.8 \mathrm{~m}$ solution) was injected (ip) into mice from groups 3 and 4 . In the first part of the experiment (Table 1), the mortality was studied. In the second part (Table 2), a similar protocol was followed except that mice were sacrified $5 \mathrm{~min}$ after ammonium acetate injection. Blood was collected from the heart. The brains and livers were quickly removed and immediately frozen in liquid nitrogen. Ammonia and urea were measured in serum, plasma, and brain within $3 \mathrm{hr}$ after sample collection.

Ammonia and urea assays. To separate serum, blood was allowed to clot at $0^{\circ} \mathrm{C}$ for $15 \mathrm{~min}$ and centrifuged in a refrigerated centrifuge at $7000 \mathrm{~g}$ for $15 \mathrm{~min}$. Brain and liver samples were homogenized in chilled perchloric acid (1 M). Homogenates were centrifuged at $10,000 \mathrm{~g}$ for $15 \mathrm{~min}, 0-2^{\circ} \mathrm{C}$, and the supernatants were neutralized to $\mathrm{pH} 7.00$ with $1 \mathrm{~N}$ sodium hydroxide. Ammonia (7) and urea (8) were determined in the serum and supernatants.

Statistical analysis. Values are expressed as means \pm SEM. Differences were analyzed by a Student $t$ test and considered statistically significant when $\boldsymbol{P}<$ 0.05 .

\section{RESULTS AND DISCUSSION}

L-Carnitine has been reported to protect mice from ammonia toxicity $(3,4)$. To test whether L-carnitine also protects other species from ammonia toxicity, we conducted preliminary experiments in ferrets. Within $2 \mathrm{hr}$ after eating an arginine free diet, ferrets from both groups developed symptoms of hyperammonemia such as seizures, convulsions, and coma. The severity and duration of sickness was similar in the two groups. Plasma ammonia levels were not significantly different in the two groups (data not shown).

Since L-carnitine failed to protect ferrets from ammonia toxicity, we examined the effect of carnitine in mice (Tables 1 and 2) using a previously published protocol $(3,4)$. To avoid discrepancies in results due to differences in animals or chemicals, we purchased the same strain of mice and obtained L-carnitine from the same source. The only difference was that O'Connor et al. collected the blood from the tail vein, whereas we collected it from the heart, as we were unable to collect sufficient blood from the tail veins of animals administered ammonium acetate.

In preliminary experiments some symptoms of hyperammonemia such as lethargy and shivering were observed in mice injected with $8 \mathrm{mmole} / \mathrm{kg}$ of ammonium acetate. Although mice injected with $12 \mathrm{mmole} / \mathrm{kg}$ ammonium acetate showed symptoms of hyperammonemia, all mice recovered within $20 \mathrm{~min}$. This is in contrast to the findings of O'Connor et al. (4), who reported the $\mathrm{LD}_{100}$ to be 12 $\mathrm{mmole} / \mathrm{kg}$. At higher concentrations of ammonium acetate $(14-18 \mathrm{mmole} / \mathrm{kg})$, mice showed more severe symptoms of ammonia toxicity such as convulsions, seizures, and death. Severity of symptoms increased with increased dose of ammonium acetate. At a $14 \mathrm{mmole} / \mathrm{kg}$ dose, more than $70 \%$ of the mice died within 8-12 min of the ammonium acetate injection.

Mice injected only with L-carnitine exhibited no visible toxic effects during a 24-hr observation period (Table 1). However, compared to saline-treated controls, 
these animals had increased ammonia in serum and increased urea in liver and brain (Table 2). The ammonia levels in liver and brain were much lower than those of saline-treated controls.

Intraperitoneal injection of L-carnitine $(16 \mathrm{mmole} / \mathrm{kg})$ did not abolish or alleviate the symptoms of hyperammonemia induced by ammonium acetate injection. These mice succumbed as rapidly as those injected with saline plus ammonium acetate.

We found no statistically significant difference in mortality between mice treated with either saline or L-carnitine prior to ammonium acetate injection (Table 1). O'Connor $e t \mathrm{al}$. (4) reported that pretreatment with $16 \mathrm{mmole} / \mathrm{kg}$ of L-carnitine protected $100 \%$ of mice from ammonia toxicity, whereas we found that more than $75 \%$ of mice pretreated with L-carnitine died within 10 min of ammonium acetate challenge. Similar mortality rates were obtained when L-carnitine was injected $15 \mathrm{~min}$ prior to the ammonium acetate challenge (data not shown). Identical results were obtained using L-carnitine from another commercial source (Sigma).

Intraperitoneal injection of ammonium acetate into mice caused a rapid increase in serum and liver ammonia but did not alter the brain ammonia (Table 2). This may be expected, as an ip injection would cause changes in liver first. Our results are again in contrast to those of O'Connor et al. (4), who reported that brain ammonia elevated rapidly in the animals that received ammonium acetate injection. We could not compare our brain ammonia values with those of O'Connor et al. (4) because they have expressed brain ammonia as millimolars without indication of tissue concentration.

Mice treated with L-carnitine plus ammonium acetate had higher levels of ammonia in the liver than mice injected with saline plus ammonium acetate (Table 2). This is probably due to an increased load of nitrogen derived from the carnitine. Although serum and brain ammonia levels were higher in carnitineplus ammonium acetate-treated animals than those in the saline plus ammonium acetate group, the differences were not statistically significant.

O'Connor et al. (4) reported that L-carnitine induced the urea synthesis and thereby lowered blood and brain ammonia. An injection of ammonium acetate or L-carnitine caused a rapid increase in urea in liver and brain (Table 2), indicating that part of the ammonia may have been converted into urea via the urea cycle. We found that L-carnitine did not cause any additional increase in the urea levels in serum, brain, or liver above that obtained with ammonium acetate alone (Table 2).

In conclusion, our study shows that L-carnitine treatment did not protect mice or ferrets against ammonia toxicity. On the contrary, injection of L-carnitine produced an increase in the plasma ammonia levels. These results suggest that the effects of $\mathrm{L}$-carnitine on ammonia toxicity in animals require more detailed study if the results are to be used as a guide to human experimentation.

\section{SUMMARY}

Recent reports indicate that intraperitoneal administration of $\mathrm{L}$-carnitine protects mice from ammonia toxicity. We found that mice injected with $\mathrm{L}$-carnitine and 
subsequently challenged with ammonium acetate succumb as readily as mice injected with saline and the ammonium acetate. Mice pretreated with L-carnitine exhibited higher levels of liver ammonia than the saline-pretreated control mice. The ammonia and urea levels in serum and brains were similar in two groups. Our findings are in contrast to those reported previously and therefore warrants further investigation before L-carnitine can be considered as a drug to alleviate hyperammonemia in humans.

\section{ACKNOWLEDGMENTS}

This work was supported by a grant from the National Institute of Allergy and Infectious Diseases, National Institutes of Health, Bethesda, Maryland. D. R. Deshmukh is a recipient of a research career development award from the National Institutes of Health. We thank Drs. Grisolia and $O^{\prime}$ Connor for assistance in obtaining $\mathrm{L}$-carnitine.

\section{REFERENCES}

1. Batshaw, M. L., Walser, M., and Brusilow, S. W., Pediatr. Res. 14, 1316 (1980).

2. Flannery, D. B., Hsia, Y. E., and Wolf, B., Hepatology 2, 495 (1982).

3. O'Connor, J. E. Costell, M., and Grisolia, S., Neurochem. Res. 9, 563 (1984).

4. O'Connor, J. E., Costell, M., and Grisolia, S., FEBS Lett. 166, 331 (1984).

5. Deshmukh, D. R., Maassab, H. F., and Mason, M., Proc. Natl. Acad. Sci. USA 79, 7557 (1982).

6. Morris, J. G., and Rogers, Q. R., J. Nutr. 108, 1944 (1978).

7. Montzac, A., Ehrlich, G. E., and Seegmiller, J. E., J. Lab. Clin. Med. 66, 526 (1965).

8. Cerriotti, G., Clin. Chem. 17, 400 (1971). 